\title{
Influence of Root Reinforcement of Forest Species on the Slope Stability of Sierra Madre Oriental, Mexico
}

\section{Sanchez-Cast illo, Laura}

Laboratory of Forest Conservation and Erosion Control, Department of Agro-environmental Sciences, Faculty of Agriculture Kyushu University | Department of Forest and Biomaterial Sciences, Faculty of Agriculture, Kyoto University : Research Fellow

Kubota, Tetsuya

Laboratory of Forest Conservation and Erosion Control, Department of Agro-environmental Sciences, Faculty of Agriculture, Kyushu University

\section{Hasnawir}

Laboratory of Forest Conservation and Erosion Control, Department of Agro-environmental Sciences, Faculty of Agriculture Kyushu University | Environment and Forestry Research and Development, Institute of Makassar, Ministry of Environment and Forestry of Indonesia

\section{Cantu-Si lva, Israel}

Laboratory of Forest Conservation and Erosion Control, Department of Agro-environmental Sciences, Faculty of Agriculture Kyushu University | Faculty of Forestry Sciences, Autonomous University of Nuevo Leon, Carretera Nacional Km

https://doi.org/10.5109/1801779

出版情報：九州大学大学院農学研究院紀要. 62 (1)，pp.177-181，2017-02-24. Faculty of Agriculture, Kyushu University

バージョン :

権利関係 : 


\title{
Influence of Root Reinforcement of Forest Species on the Slope Stability of Sierra Madre Oriental, Mexico
}

\author{
Laura SANCHEZ-CASTILLO ${ }^{1 *}$, Tetsuya KUBOTA ${ }^{2}$, HASNAWIR $^{3}$ \\ and Israel CANTU-SILVA ${ }^{4}$
}

\author{
Laboratory of Forest Conservation and Erosion Control, Department of Agro-environmental Sciences, \\ Faculty of Agriculture Kyushu University, Fukuoka 812-8581 \\ (Received October 17, 2016 and accepted November 4, 2016)
}

\begin{abstract}
Soil erosion and sediment related disasters are one of the most serious environmental problem in Mexico, mainly product of deforestation practices, land use changes and hydro-meteorological events like heavy rainfalls and hurricanes. The application of vegetative measures to restore affected sites should be a priority on mountainous countries like Mexico. The objectives of this study are to estimate the soil reinforcement by roots and to analyze the increment of Factor of safety (Fs) of a studied slope on Sierra Madre Oriental, Mexico from two different scenarios: rainfall and no-rainfall. The estimation of the additional soil reinforcement provided by roots $(\Delta S)$ of the four species analyzed ranged from 0.01 to $0.22 \mathrm{kN} / \mathrm{m}^{2}$ (Quercus rysopylla), from 0.006 to $0.08 \mathrm{kN} / \mathrm{m}^{2}$ (Pinus pseudostrobus), from 0.01 to $0.46 \mathrm{kN} / \mathrm{m}^{2}$ (Acacia berlandieri) and from 0.01 to $0.05 \mathrm{kN} / \mathrm{m}^{2}$ (Ligustrum lucidum). The results of the finite element method (FEM) analysis in the different scenarios indicate that the slope is in a stable condition. However, the presence of roots on the slope have a bigger positive effect during rainfall conditions, the Fs increment is especially notable in Acacia berlendieri (6.36\%) and Quercus rysopylla (3.63\%). In other hand, in no-rainfall conditions the $\mathrm{F}_{\mathrm{s}}$ increment for the same species is Acacia berlendieri (4\%) and Quercus rysopylla (1.71\%). The species that contributed the best to the stability of the studied slope was Acacia berlendieri followed by Quercus rysopylla, Pinus pseudostrobus and Ligustrum lucidum. The $\mathrm{F}_{\mathrm{s}}$ improvement due the roots of the species living in Sierra Madre Oriental, Mexico is a very important contribution to understand and to clarify the forest species potential contribution to slope stabilization in the study area.
\end{abstract}

Key words: Slope stability, Tree roots, Mexico, Sierra Madre

\section{INTRODUCTION}

Soil erosion and sediment related disasters are one of the most serious environmental problems in Mexico, where, $24 \%$ of the total soil is highly degraded or affected by sediment related disasters as result of deforestation or land use changes. Previous studies have demonstrated that the absence of vegetation increases the erosion in the urbanized forest area. In recent years, meteorological events such as heavy rainfall and hurricanes had magnified the problems in the Sierra Madre Oriental forest slopes. The application of vegetative measures to restore the affected sites could be significant as are ecologically friendly, low in costs and easy in techniques.

The beneficial influence of vegetation on slope stabilization includes modifications of soil moisture, buttressing and arching of roots, surcharge of vegetation biomass above the ground and soil reinforcement by plant roots (Gray and Sotir, 1996). Soil reinforcement is a contribu-

\footnotetext{
1 Department of Forest and Biomaterial Sciences, Faculty of Agriculture, Kyoto University, Kyoto 606-8502

2 Laboratory of Forest Conservation and Erosion Control, Department of Agro-environmental Sciences, Faculty of Agriculture, Kyushu University, Fukuoka 812-8581

Environment and Forestry Research and Development Institute of Makassar, Ministry of Environment and Forestry of Indonesia, Makassar 90243

${ }^{4}$ Faculty of Forestry Sciences, Autonomous University of Nuevo Leon, Carretera Nacional Km. 145, Linares, Nuevo León, México 67700

* Corresponding authors (E-mail: laura@kyudai.jp, kubot@agr. kyushu-u.ac.jp)
}

tory factor in slope stabilization and is widely investigated and used for site restorations (Waldron, 1977; Wu et al., 1979, Sanchez-Castillo et al., 2014; Zhang et al., 2015).

Roots of forest species increases the shear strength of soil mainly by transferring shear stresses that develop in the soil into tensile resistance, when the shear of the slope makes the fiber deform and causes elongation, which provides enough interface friction and confining stress to lock fiber on place and prevent slippage or pull out. The use of the perpendicular model for the estimation of root reinforcement is a very useful estimation and is supported by laboratory and statistical studied with randomly distributed fibers (Gray and Ohashi, 1983; Maher and Gray, 1990).

This study aims to estimate the soil reinforcement by roots and to analyze the increment of safety factor in forest slope of Chipinque National Park of Sierra Madre Oriental, Mexico.

\section{MATERIALS AND METHODS}

\section{Study area}

The study was carried out in the slopes of Chipinque National Park in Monterrey, Nuevo Leon, Mexico. Chipinque National Park is located in Cumbres of Monterrey National Park in the northern portion of Sierra Madre Oriental (Fig. 1). This National Park was established in 1939 to protect the native flora and fauna against the spreading urbanization of Monterrey city. The climate in the park changes drastically depending on the elevation and the location; Following Köppen classi- 
fication the following climates are observed in the park. Elevation 600-1,000 m; North tip of the park has a (BWh) desert climate with an average annual temperature of $23^{\circ} \mathrm{C}$ and an annual precipitation of $217 \mathrm{~mm}$. Elevation 1,000-2,000 m: North tip and the southwest corner of the park has a (BSk) Steppe Climate with an average annual temperature $21^{\circ} \mathrm{C}$. Elevation 2,000-3,000 m: Western side of the park has a (Cwb) Oceanic climate with an average annual temperature of $14^{\circ} \mathrm{C}$ and an annual precipitation of $680 \mathrm{~mm}$. The general vegetation consists of Mixed Pine-Oak forest with species like: Pinus cembroides, Pinus hartwegii, Pinus pinceana, Pinus pseudostrobus, Pinus rudis, Pinus teocote. and Oaks like: Quercus fusiformis, Quercus greggii, Quercus hipoxlanta, Quercus laeta, Quercus rysophylla. And also submontane shrubs in lower parts with species like: Acacia berlindieri, Acacia rigidula, Leucophillum frutescens and Cordia boissieri (Secretariat of Sustainable Development of Nuevo Leon state, 2013).

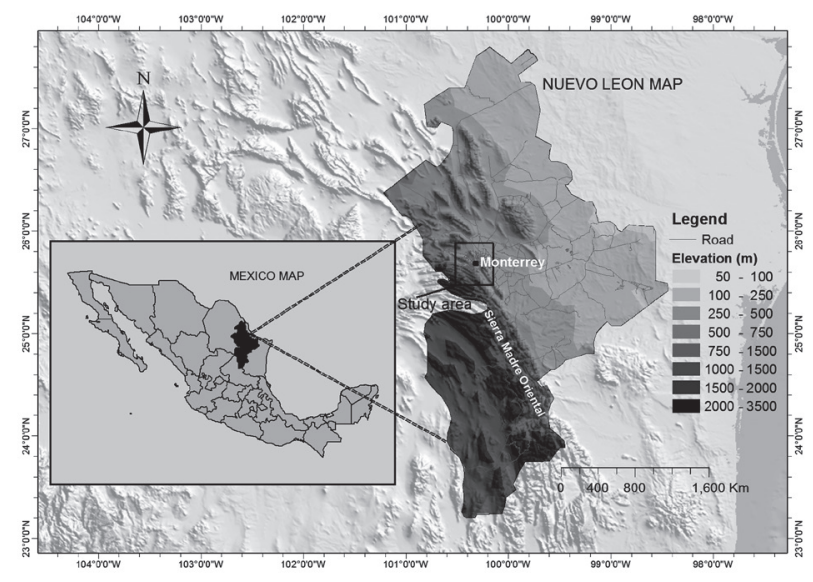

Fig. 1. Study area in Sierra Madre Oriental, Nuevo Leon, Mexico.

\section{Methods}

Soil-root reinforcement estimation

Four forest species were selected based on their native characteristics and/or widespread distribution in the slopes of Chipinque National Park in Sierra Madre Oriental, Nuevo Leon: Quercus rysophylla, Pinus pseudostrobus, Acacia berlandieri and Ligustrum lucidum. Specimens with root system exposed were selected and root samples were collected, carefully labeled and transported to laboratory for the tensile strength tests. On field, pictures were taken to calculate root area ratio that is defined as the fraction of the soil cross-sectional area occupied by roots per unit area (Gray and Leiser, 1982). The method of root counting by image analysis described by Vogt and Persson (1991) was used to calculate root area ratio, which consists on the mapping and counting of the exposed roots on a trench from images in order to calculate the cross-sectional area and recreate the root system, this method emulates the traditional profile wall method proposed by Bohm (1979).
The tensile strength of an individual root was measured using the universal testing machine Shimazu type SLFL-100 kN following the next procedure: root samples were carefully positioned and were clamped to experimental devices in both extremities. The diameters were measured using a digital caliper Mitutoyo in three different points and the mean diameter was calculated to assign a representative value corresponding to the breaking point of each sample. Root samples were pulled at a constant speed of $10 \mathrm{~mm} / \mathrm{min}$. Tensile strength values were measured by the machine load cell and recorded with a data logger. Data was visualized and outputted using the material testing operation software Trapezium $\mathrm{X}$.

The influence of roots on soil reinforcement can be expressed as cohesion term (O'Loughlin, 1974; Wu, 1976; Waldron, 1977) in the Morh-Coulomb failure criteria were the soil-root composite shear strength is calculated as follows:

$$
S_{r}=c^{\prime}+(\sigma-u) \tan \phi^{\prime}+\Delta S
$$

where $c^{\prime}$ is the effective cohesion of the soil, $\sigma$ is the normal stress due the weight of the water and soil of sliding mass, $u$ is the soil pore-water pressure, $\phi^{\prime}$ is the effective friction angle of the soil and $\Delta S$ is the apparent cohesion provided by the presence of roots.

The theoretical model developed by Wu (1976), Waldron (1977) and Wu et al. (1979) was used to estimate the shear strength increase due the presence of roots. This model assumes that roots are flexible, elastic and perpendicular oriented to the slip surface, when the soil layer is moving. The mobilization of tensile resistance of the fibres can be translated into tangential and normal components. Assuming that soil friction angle is not affected (O'Loughlin, 1974) the additional cohesion provided by roots can be calculated as:

$$
\Delta S=t_{r}\left(\sin \beta+\cos \beta \tan \phi^{\prime}\right)
$$

where $t_{r}$ is the average mobilized tensile strength of roots per unit area of the soil and $\beta$ is the angle of root distortion in the shear zone. Sensitivity analyzes show that the values of $\left(\sin \beta+\cos \beta \tan \phi^{\prime}\right)$ can be approximated as 1.2 for $30^{\circ}<\phi^{\prime}<40^{\circ}$ and $48^{\circ}<\beta<72^{\circ}$ (Wu et al., 1979; Wu, 1995). Thus, equation can be simplified as:

$$
\Delta S=1.2 t_{r}
$$

and $t_{r}$ can be calculated as:

$$
t_{r}=\sum_{\mathrm{i}=0}^{\mathrm{n}} T_{r i}\left(A_{r i} \mid A\right)
$$

where $T_{r i}$ is the tensile strength of an individual root (i) and $\left(A_{r i} \mid A\right)$ is the root area ratio or proportion of root cross sectional area to soil cross sectional area A.

- Slope stability analysis

The slope fails because the shear strength of its material is not sufficient to endure the shear stresses to 
which is being subjected from its surface. The factor of safety against the slope failure can be calculated as:

$$
F s=\frac{\tau_{f}}{\tau}
$$

where $\tau_{f}$ is the shear strength of the slope material, which is calculated through Coulomb's criterion as:

$$
\tau=c+\sigma_{n} \tan \phi
$$

and $\tau$ is the shear stress on the slip surface. It can be calculated as:

$$
\tau_{f}=c_{f}+\sigma_{n} \tan \phi_{f}
$$

where the factors shear strength parameters $C_{f}$ and $\phi_{f}$ are:

$$
\begin{aligned}
& c_{f}=\frac{c}{S R F} \\
& \phi_{f}=\tan ^{-1}\left(\frac{\tan \phi}{S R F}\right)
\end{aligned}
$$

where $S R F$ is strength reduction factor. This method has been referred to as the 'shear strength reduction method' (SSR). It is a simple approach that involves a systematic search for a stress reduction factor (SRF) or factor of safety value that brings a slope failure limits (Hammah et al., 2004). To achieve the correct $S R F$, it is essential to trace the value of Fs that will just cause the slope to fail. In the finite element method, a continuum is divided into "elements" that are separated by imaginary lines or surfaces and are assumed to be interconnected only at a finite number of nodal points situated on the boundaries (Matsui and San, 1992; Dawson et al., 1999; Zienkiewicz and Taylor, 2000; Hammah et al., 2004). In this study slope stability analysis is performed using the finite element method (FEM) with strength reduction technique in 2 dimensions by FEM computer code developed by Geotechnical Laboratory of Gunma University GUSLOPE Version 1.00. The FEM analysis was conducted adding the coefficient of additional cohesion provided by roots $(\Delta S)$ to the soil properties of the slope, in

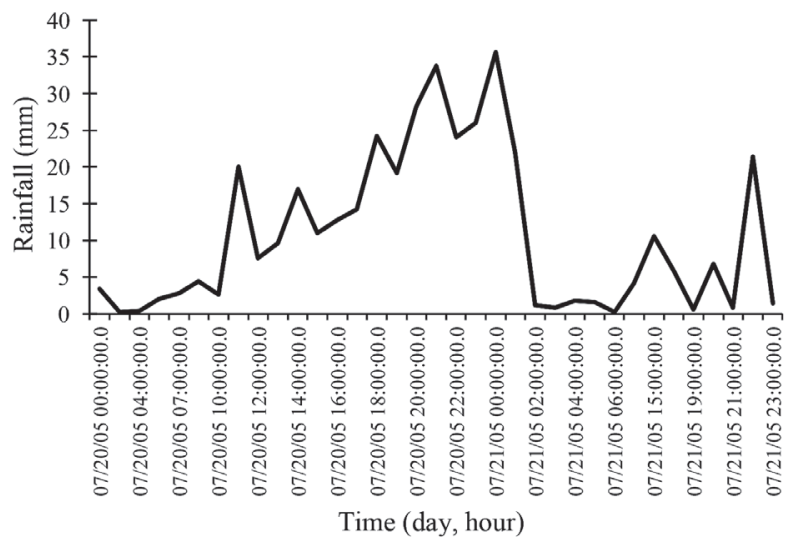

Fig. 2. Rainfall condition during hurricane "Emily" in 2005. two different scenarios: with rainfall and without rainfall. Rainfall information during hurricane "Emily" in 2005 was used (Fig. 2). The rainfall condition presented during hurricane Emily was used because follows the pattern observed in previous disastrous events: High intensity of rainfall during a very short duration (less than $24 \mathrm{hrs}$ ), similar rainfall patterns have been described as triggering factors of sediment related disasters in previous studies (Larsen and Simon, 1993; Crosta and Frattini, 2001; Guzzeti et al., 2008; Saito et al., 2014; Chen, 2016)

\section{RESULTS AND DISCUSSION}

\section{Soil reinforcement by roots}

The additional soil reinforcement provided by roots $(\Delta S)$ for the four species are analyzed ranged from 0.01 to $0.22 \mathrm{kN} / \mathrm{m}^{2}$ (Quercus rysophylla), from 0.006 to 0.08 $\mathrm{kN} / \mathrm{m}^{2}$ (Pinus pseudostrobus), from 0.01 to $0.46 \mathrm{kN} / \mathrm{m}^{2}$ (Acacia berlandieri) and from 0.01 to $0.05 \mathrm{kN} / \mathrm{m}^{2}$ (Ligustrum lucidum). Distribution of minimum, maximum and average values is showed in Fig. 3.

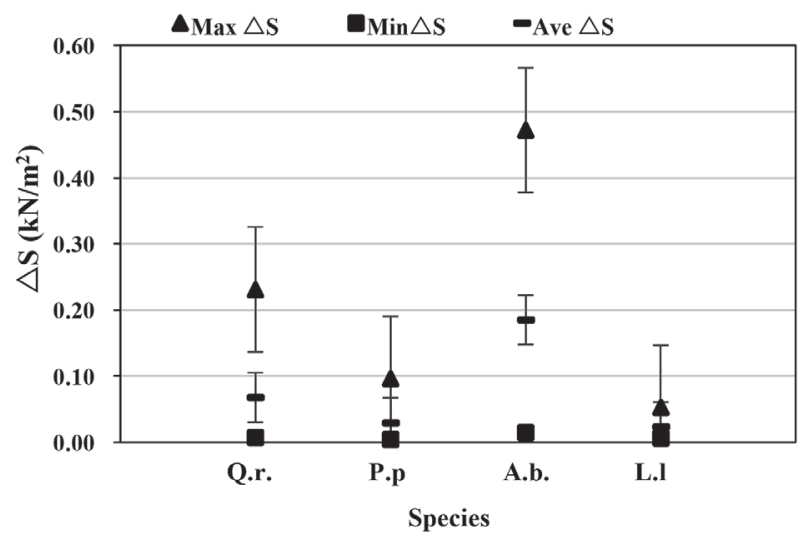

Fig. 3. The additional soil reinforcement provided by roots $(\Delta S)$. (Q.r.= Quercus rysophylla, P.p.= Pinus pseudostrobus, A.b.=Acacia berlandieri, L.l.= Ligustrum lucidum).

The coefficient of additional soil reinforcement provided by roots depends on quality of root material expressed as root area ratio (RAR) at the shear plane, that is why comparison with the results of other studies is difficult as the results typically reported, which have a big spatial variability (Burroughs and Thomas, 1977; O'Loughlin and Watson, 1979; Ziemer, 1981; Coppin and Richards, 1990; Abernethy and Rutherfurd, 2001). Root area ratio declines sharply with depth, because the roots samples tested in this study correspond to small diameters far from the trunk, due to test machine limitations, values are quite low comparing other studies (Morgan and Rickson, 1995; Abernethy and Rutherfurd, 2001; Tosi, 2007). Besides root area ratio and subsequently root reinforcement is influenced by species genetic, conditions and soil and slope characteristics (Bischetti et al., 2005; Stokes et al., 2002) which limit results to a regional area. 


\section{Slope stability analysis}

The results of FEM analysis are described as the factor of safety (Fs), when the factor of safety is 1.0 or bigger means the slope is in a stable condition, but when the factor of safety is minor than 1.0 indicates that slope is in an unstable condition. A slope model was delimited (Fig. 4) with soil properties showed in Table 1, the maximum values of coefficient of additional cohesion provided by roots $(\Delta S)$ were added as: Quercus rysophylla: 0.22 $\mathrm{kN} / \mathrm{m}^{2}$; Pinus pseudostrobus: $0.08 \mathrm{kN} / \mathrm{m}^{2}$; Acacia berlandieri; $0.46 \mathrm{kN} / \mathrm{m}^{2}$; and Ligustrum lucidum: $0.05 \mathrm{kN} /$ $\mathrm{m}^{2}$.

The factor of safety in the two scenarios without the presence of roots resulted as Fs $=1.1$ during rainfall conditions and Fs $=1.75$ without rainfall conditions. The slope under normal conditions is stable in both scenarios. However, the objective of this study is to find out the effect of roots of forest species on the stability of slopes, for this purpose the coefficient of additional cohesion provided by roots $(\Delta S)$ was added to the soil properties of the slope model. The increases of Fs without rainfall was as follows: from Fs $=1.75$ to $F s=1.78$ (Quercus rysophylla); Fs $=1.76$ (Pinus pseudostrobus); Fs $=1.82$ (Acacia berlandieri); Fs=1.75 (Ligustrum lucidum). During rainfall conditions from $F s=1.1$ to $F s=1.14$ (Quercus rysophylla); Fs=1.12 (Pinus pseudostrobus): $F s=1.17$ (Acacia berlandieri); $F s=1.11$. (Ligustrum lucidum) (Table 2). Clearly, the Fs of the studied slopes is incremented due the presence of roots in some percentage, in agreement with previous studies (Abernethy and Rutherfurd, 2001; Simon and Collinson 2002; Pollen and Simon, 2005; Tosi, 2007; Docker and Hubble 2008).

\section{CONCLUSIONS}

The results of additional soil reinforcement provided by roots $(\Delta S)$ for the four species analyzed ranged from

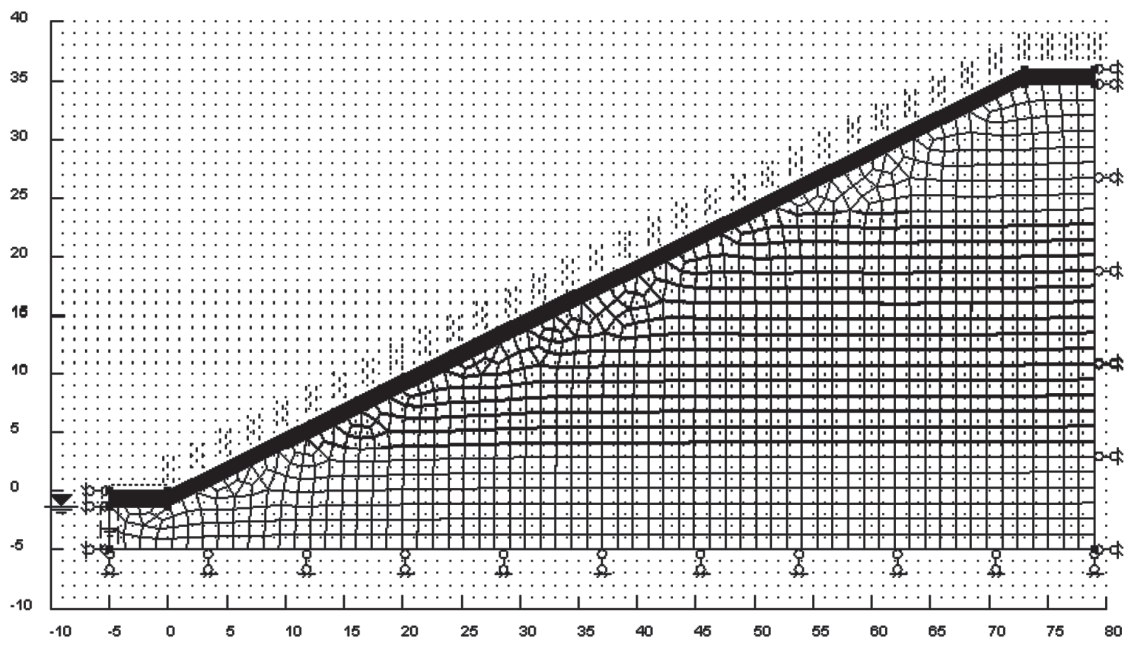

Fig. 4. Slope model used for the FEM analysis.

Table 1. Soil properties of the studied slope

\begin{tabular}{lcccccc}
\hline Layers/parameters & $\begin{array}{c}\gamma \\
\left(\mathrm{kN} / \mathrm{m}^{3}\right)\end{array}$ & $\begin{array}{c}\mathrm{C} \\
\left(\mathrm{kN} / \mathrm{m}^{2}\right)\end{array}$ & $\begin{array}{c}\Phi \\
(\text { degree })\end{array}$ & $\begin{array}{c}\mathrm{E} \\
\left(\mathrm{kN} / \mathrm{m}^{2}\right)\end{array}$ & $\begin{array}{c}\mathrm{k} \\
(\mathrm{cm} / \mathrm{s})\end{array}$ \\
\hline Surface & 18 & 3 & 35 & 20000 & $8 \times 10-4$ \\
Bedrock & 26 & 1000 & 40 & 400000 & 0.3 & $2.5 \times 10-10$ \\
\hline
\end{tabular}

Table 2. FEM results of analyzed slope in the different scenarios

\begin{tabular}{lccc|ccc}
\hline Species & $\mathrm{F}_{\mathrm{s}}(\mathrm{R})$ & $\rightarrow$ & $\mathrm{F}_{\mathrm{s}} \Delta S(\mathrm{R})$ & $\mathrm{F}_{\mathrm{s}}(\mathrm{NR})$ & $\rightarrow$ & $\mathrm{F}_{\mathrm{s}} \Delta S(\mathrm{NR})$ \\
\hline Quercus rysophylla & 1.10 & $\rightarrow$ & 1.14 & 1.75 & $\rightarrow$ & 1.78 \\
Pinus pseudostrobus & 1.10 & $\rightarrow$ & 1.12 & 1.75 & $\rightarrow$ & 1.76 \\
Acacia berlandieri & 1.10 & $\rightarrow$ & 1.17 & 1.75 & $\rightarrow$ & 1.82 \\
Ligustrum lucidum & 1.10 & $\rightarrow$ & 1.11 & 1.75 & $\rightarrow$ & 1.75
\end{tabular}

$\mathrm{F}_{\mathrm{s}}(\mathrm{R})=$ Factor of safety without roots presence in rainfall conditions; $\mathrm{F}_{\mathrm{s}} \Delta S(\mathrm{R})=$ Factor of safety with roots presence in rainfall conditions; $\mathrm{F}_{\mathrm{s}}(\mathrm{NR})$ = Factor of safety without roots presence in dry conditions; $\mathrm{F}_{\mathrm{s}} \Delta S(\mathrm{NR})=$ Factor of safety with roots presence in dry conditions. 
0.01 to $0.22 \mathrm{kN} / \mathrm{m}^{2}$ (Quercus rysophylla), from 0.006 to $0.08 \mathrm{kN} / \mathrm{m}^{2}$ (Pinus pseudostrobus), from 0.01 to 0.46 $\mathrm{kN} / \mathrm{m}^{2}$ (Acacia berlandieri) and from 0.01 to $0.05 \mathrm{kN} /$ $\mathrm{m}^{2}$ (Ligustrum lucidum). The results of the finite element method (FEM) analysis in the different scenarios indicate that the slope is in a stable condition. However, the presence of roots on the slope have a bigger positive effect during rainfall conditions, the $\mathrm{F}_{\mathrm{s}}$ increment is especially notable in Acacia berlendieri (6.36\%) and Quercus rysophylla (3.63\%). In other hand, in norainfall conditions the Fs increment for the same species is Acacia berlendieri (4\%) and Quercus rysophylla $(1.71 \%)$. The species that contributed the best to the stability of the studied slope was Acacia berlendieri followed by Quercus rysophylla, Pinus pseudostrobus and Ligustrum lucidum. The root area ratio in the applied model was observed as the factor that influences the coefficient of additional cohesion provided by roots on the slope. All species considered for this study contributed to the stability of slope in a positive way. The $\mathrm{F}_{\mathrm{s}}$ improvement due the roots of the species living in Chipinque National Park of Sierra Madre Oriental, Nuevo Leon is a very important information to understand the potential contribution to slope stabilization of each forest species in the study area.

\section{REFERENCES}

Abernethy, B., and I.D Rutherfurd. 2001. The distribution and strength of riparian tree roots in relation to riverbank reinforcement. Hydrological processes, 15(1): 63-79

Bischetti, G. B., E.A Chiaradia, T, Simonato, B Speziali, B Vitali, P Vullo, P and A Zocco. 2005. Root strength and root area ratio of forest species in Lombardy (Northern Italy). Plant and soil, 278(1-2): 11-22

Bohm, W. 1979. Methods of Studying Root Systems. SpringerVerlag, Berlin Heidelberg, New York

Burroughs, E. R. Jr., and B. R. Thomas. 1977. Declining root strength in Douglas-fir after felling as a factor in slope stability, USDA Forest Service Research Paper INT-190. 27

Chen, C. 2016. Landslide and debris flow initiated characteristics after typhoon Morakot in Taiwan. Landslides 13(1): 153-164

Coppin, N. J and I.G. Richards. 1990. Use of vegetation in civil engineering. London: Construction Industry Research and Information Association

Crosta, G. B and P. Frattini. 2001. Rainfall thresholds for triggering soil slipes and debris flow. In: Mugnai A, Guzzeti F, Roth G (eds) Mediterranean storms. Proceedings of the $2^{\text {nd }}$ EGS Plinius Conference on Mediterranean Storms, Siena, Italy, 153-487

Dawson, E. M., W. H Roth and A. Drescher. 1999 Slope stability analysis by strength reduction, Geotechnique. 49(6): 835-840

Docker, B. B. and T. C. T. Hubble. 2008. Quantifying root-reinforcement of river bank soils by four Australian tree species. Geomorphology, 100(3): 401-418

Gray, D. H. and A. T. Leiser. 1982. Biotechnical Slope Protection and Erosion Control. Van Nostrand Reinhold Company: New York

Gray, D. H., and H. Ohashi. 1983. Mechanics of fiber reinforcement in sands. J. Geotech. Eng., 109(3): 335-353

Gray, D. H. and R. B. Sotir. 1996. Biotechnical and soil bioengineering slope stabilization: a practical guide for erosion control. John Wiley and Sons, New York

Guzzeti, F., S Peruccacci, M. Rossi, Stark C. P. 2008. The rainfall intensity-duration control of shallow landslides and debris flows: an update. Landslides $\mathbf{5}(1)$ : 3-17
Hammah, R. E., J. H. Curran, T. E. Yacoub, and B. Corkum. 2004. Stability analysis of rock slopes using the finite element method. In Proceedings of the ISRM regional symposium EUROCK

Larsen, M. C. and Simon, A., 1993: A rainfall intensity-dura- tion threshold for landslides in a humid-tropical environ- ment, Puerto Rico. Geogr. Ann. 75A(1-2): 13-23

Maher, M. H., and D. H. Gray. 1990. Static response of sand reinforced with fibres. J. Geotech. Eng., 116(11): 1661-1677

Matsui, T. and K. C. San. 1992 Finite element slope stability analysis by shear strength reduction technique, Soils and Foundations. 32(1): 59-70.

Morgan, R. P. C. and R. J. Rickson. 1995. Water Erosion Control In slope stabilization and erosion control: a bioengineering approach, Morgan, R. P. C. and R. J Rickson. (eds), E \& FN Spon, London, 133-190

O'loughlin, C. L. 1974. The effect of timber removal on the stability of forest soils. Journal of Hydrology, 13(2): 121-134

O'loughlin, C. L., and A. L. E. X. Watson. 1979. Root-wood strength deterioration in radiata pine after clearfelling. NZJ For. Sci, 9(3): 284-293

Pollen, N. and A. Simon. 2005. Estimating the mechanical effects of riparian vegetation on stream bank stability using a fiber bundle model. Water Resources Research, 41(7): 1-11

Saito H., O. Korup, T. Uchida, S. Hayashi, T. Oguchi. 2014. Rainfall conditions, typhoon frequency, and contemporary landslide erosion in Japan. Geology 42(11): 999-1002

Sanchez-Castillo, L., T. Kubota, I. Cantu-Silva. 2014. Root Strength Characteristics of Understory Vegetation Species for Erosion Mitigation on Forest Slopes of Mexico. International Jourmal of Ecology and Development, 28(2): 1-8

Secretariat of Sustainable Development of Nuevo Leon state, 2013. Atlas of risk for the state of Nuevo Leon, 1: 8-22

Simon, A and A. J. Collison. 2002 Quantifying the mechanical and hydrologic effects of riparian vegetation on streambank stability. Earth Surface Processes and Landforms 27(5): 527-546

Stokes, A., T. Fourcaud, J. Hruska, J. Cermak, N. Nadyezdhina, V. Nadyezhdin, and L. Praus. 2002. An evaluation of different methods to investigate root system architecture of urban trees in situ: I. Ground-penetrating radar. Journal of Arboriculture, 28(1): 2-10

Tosi, M. 2007. Root tensile strength relationships and their slope stability implications of three shrub species in the northern Apennines (Italy). Geomorphology 87: 268-283

Vogt, K. A. and H. Persson. 1991, Measuring growth and development of roots. Techniques and approaches in forest tree ecophysiology, 477-501

Waldron, L. J. 1977 The shear resistance of root-permeated homogeneous and stratified soil. Soil Science Society of America Journal, 41(5): 843-849

Wu, T. H. 1976. Investigation of landslides on Prince of Wales Island, Alaska. Ohio State University Department of Civil Engineering, Geotechnical Engineering Report 5: 93

Wu, T. H., I. I. I Mckinnell and D. N. Swanston. 1979. Strength of tree roots and landslides on Prince of Wales Island, Alaska. Canadian Geotechnical Journal 16(1): 19-33

$\mathrm{Wu}, \mathrm{T}$. H. 1995. Slope stabilization. In: Morgan RPC, Rickson $R J$ (eds) Slope stabilization and erosion control, a bioengineering approach. E\&FN Spon, London, pp. 221-264

Ziemer, R. R. 1981. The role of vegetation in the stability of forested slopes. Proceedings of the International Union of Forestry Research Organizations, XVII World Congress, 6-17 September 1981, Kyoto, Japan. 1: 297-308

Zhang, C., J. Jiang, J. Ma, X. Zhang, Q. Yang, Q. Ouyang and X. Lei. 2015. Evaluating soil reinforcement by plant roots using artificial neural networks. Soil Use and Management, 31: 408416

Zienkiewicz, O. C and R. L. Taylor. 2000. The finite element method (Fifth Edision) Vol. 3. Fluid Dynamics. ButterworthHeinemann. Woburn, MA 